Article

\title{
Nuclear Magnetic Resonance and Calorimetric Investigations of Extraction Mode on Flaxseed Gum Composition
}

\author{
Fang Dubois ${ }^{1}$, Corentin Musa ${ }^{1}$, Benoit Duponchel ${ }^{2}$, Lucette Tidahy ${ }^{1}$, Xavier Sécordel ${ }^{3}$, \\ Isabelle Mallard ${ }^{1}$ and François Delattre ${ }^{1, *}$ \\ 1 Littoral Côte d'Opale University, UR 4492, UCEIV, Unité de Chimie Environnementale et Interactions sur le \\ Vivant, SFR Condorcet FR CNRS 3417, 145 Avenue Maurice Schumann, 59140 Dunkerque, France; \\ fang.duboisyu@gmail.com (F.D.); corentin.musa@gmail.com (C.M.); lucette.tidahy@univ-littoral.fr (L.T.); \\ isabelle.mallard@univ-littoral.fr (I.M.) \\ 2 Littoral Côte d'Opale University, UR 4476, UDSMM, Unité de Dynamique et Structure des Matériaux \\ Moléculaires, 145 Avenue Maurice Schumann, 59140 Dunkerque, France; benoit.duponchel@univ-littoral.fr \\ 3 Littoral Côte d'Opale University, UR 4493, LPCA, IRenE, 145 Avenue Maurice Schumann, 59140 Dunkerque, \\ France; xavier.secordel@univ-littoral.fr \\ * Correspondence: delattre@univ-littoral.fr
}

Received: 20 October 2020; Accepted: 5 November 2020; Published: 11 November 2020

check for updates

\begin{abstract}
We discussed about the influence of extraction mode on the flaxseed gums composition and their thermal stabilities. In order to do so, flaxseed gum was extracted by both classical magnetic stirring method and ultrasonic-assisted extraction (UAE). As a function of time, protein content, gum yield, $\mathrm{pH}$ values were evaluated and samples were characterized by ${ }^{1} \mathrm{H}$ and ${ }^{13} \mathrm{C}$ nuclear magnetic resonance (NMR) experiments as well as scanning electron microscopy (SEM), differential scanning calorimetry (DSC) and thermal gravimetric analysis (TGA). The flaxseed gum extracted in aqueous solution correspond to a mixture of different components, including polysaccharides, proteins and sometimes lignan derivatives. It is found that the protein and gum contents increase with the extraction duration for both the ultrasonic assisted and the traditional extraction while the $\mathrm{pH}$ decreases at the same time. As expected, compared to traditional magnetic stirring method, ultrasonic assisted extraction method can significantly enhance the yield of polysaccharides, lignans and proteins. The variation of $\mathrm{pH}$ is correlated to the increase of lignan molecules in the extracted samples. For thermic methods, SEM experiments showed that lignan derivatives which ester-bonded to polysaccharides associated to proteins are responsible to the formation of globular aggregates. Supplementary rod-like molecular organization were obtained from UAE and questions on the nature of the amphiphilic mesogen carbohydrate structures.
\end{abstract}

Keywords: flaxseed gum; polysaccharide; ultrasonic-assisted extraction

\section{Introduction}

With concerns to various environmental issues, materials derived from plants that are biodegradable in nature upon disposal have been paid enormous attention in recent years. Among available raw materials, mucilage or gum is a substance that occurs naturally in some plants, where it acts as the role to keep water. It is a fraction of plant polysaccharides with varying compositions that can become viscous in the presence of water. Therefore, it is also called a translucent and amorphous vegetable hydrocolloid, resulting from the polymerization of a monosaccharide or mixtures of several types of sugars, and many of them combining with uronic acids. So far, the mucilage from many plants has been studied and among them, mucilage from flaxseeds has been 
shown considerable potential to have wide and promising applications ranging from food industry to cosmetics and medical health care [1,2]. This complex polymeric substance of carbohydrate nature with a highly branched structure contains varying proportions of L-arabinose, D-galactose, L-rhamnose and D-xylose, as well as galacturonic acid. It has been reported that the neutral fraction of flaxseed mucilage contains L-arabinose, D-xylose, and D-galactose, and the acidic fraction contains L-rhamnose, L-fucose, L-galactose and D-galacturonic acid [3,4]. The neutral fraction consists of an arabinoxylan derivative having a $(1 \rightarrow 4)-\beta$-D-xylan backbone to which arabinose and galactose sidechains are attached at positions 2 and/or 3 [3]. The acidic fraction owns a backbone of $(1 \rightarrow 2)$-linked $\alpha$-L-rhamnopyranosyl and $(1 \rightarrow 4)$-linked D-galactopyranosyluronic acid residues, with side-chains of fucose and galactose residues, the former being mostly located at the non-reducing end.

The optimization of flaxseed hydrosoluble compounds extraction (polysaccharides, proteins, mineral salts ... ) can be monitored by various parameters such as time, temperature, $\mathrm{pH}$ as well as stirring velocity [5-10]. It has been shown that concentration and composition of gums and consequently physicochemical properties are affected by the operational parameters. Apart from thermic proceeding, ultrasonic assisted extraction (UAE) has been described as the most used eco-friendly technique to improve the extraction efficiency of the mucilage [11]). Three interconnected mechanisms have been described by Mason [12] through which ultrasound can enhance the efficiency of the extraction process by providing better mass transfer: (i) plant cells breaking down via the formation of microjets due to asymmetrical bubble collapsing near a solid surface; (ii) enhanced analytes solubility and solvent penetration due to the increase in localized temperature and pressure in the zone of bubble implosion; and (iii) enhanced diffusion as a consequence of the microstreaming generated by ultrasound. The ultrasonic assisted extraction shows a second order kinetics with respect to mucilage concentration while the extraction by traditional magnetic stirring exhibits first-order kinetics, and therefore an extraction duration of $30 \mathrm{~min}$ is reported to be sufficient to achieve quantitative extraction of the mucilage. It is also reported that the recovered mucilage is found to have less proteins and higher concentration of valuable pentoses. Otherwise, Alix et al. [13] have reported that higher amount of protein content was recovered during with the traditional magnetic stirring extraction method at higher temperature. However, no detailed studies were reported on the evolution of the flaxseed gum composition according to different extraction parameters for both traditional and ultrasonic assisted extraction. The involvement of protein extracted with mucilage is not well defined in regard to the performance of mucilage. Furthermore, only few studies have been conducted concerning the thermal properties of flaxseed mucilage. Their thermal stability or their use as eco-friendly thermal plastic films has not yet been investigated.

In this present work, we have executed both the ultrasonic assisted and thermal extraction of flax seed mucilage with varying extraction parameters in order to quantify the protein content extracted together with the mucilage with different extraction parameters as well as its effect on the physical performance of gum. ${ }^{1} \mathrm{H}$ and ${ }^{13} \mathrm{C}$ nuclear magnetic resonance (NMR) were further conducted to state information about the components presented in the extracted mucilage mixtures. Then, the morphologies of the extracted samples were characterized by scanning electron microscopy (SEM) and the thermal properties of the hydrocolloid mixtures were investigated and discussed by differential scanning calorimetry (DSC), and thermal gravimetric analysis (TGA).

\section{Materials and Methods}

\subsection{Material and Reagents}

Flax seeds (Aramis) produced commercially in North France (Van Robaeys Frères, France) was used as the raw material for the extraction of mucilage. $\mathrm{D}_{2} \mathrm{O}$ was used as NMR solvent for ${ }^{1} \mathrm{H}$ and ${ }^{13} \mathrm{C}$ NMR characterization. Resorcinol (99\%), hydroxydiphenyl solution and L-arabinose were purchased from Sigma-Aldrich (Saint-Louis, MO, United States). Sodium tetraborate (98\%), D-galactose (99\%) and L-fucose (97\%) were purchased from ACROS ORGANICS (Thermo Fisher Scientific Inc., 
Waltham, MA, USA). D-galacturonic acid and potassium sulfamate (98\%) were purchased from Alfa Aesar (Thermo Fisher Scientific GmbH, Kandel, Germany). D-xylose was purchased from VWR chemicals (Fontenay-sous-Bois, France). Sulfuric acid (>95\%) was purchased from Fisher chemicals (Fisher Scientific International, Inc., Pittsburgh, Pennsylvania, United States). Bicinchonic acid solution, copper (II) sulfate pentahydrate $4 \%$ solution and protein standard (Bovine Serum Albumin-BSA) were used for the protein test and were purchased from Sigma-Aldrich (Saint-Louis, MO, USA).

\subsection{Mucilage Extraction}

Flax seed mucilage was extracted in triplicate by an aqueous process with or without ultrasonic treatment at each desired program. UAE was performed in an ultrasonic pipe equipped with eight radial transducers (13 $\mathrm{mm}$ diameter horn, $22 \mathrm{kHz}$ ) from SinapTec Ultrasonic Technology (Lezennes, France). The ultrasonic pipe was connected with a NexTgen Ultrasonic Analyzer in order to monitor the developments in real time. The ultrasonic treatment was applied under pulse mode with amplitude of $40 \%$ PWM $\left(200 \mathrm{~W}_{\text {eff }}\right)$. All mucilage solutions were collected after each desired extraction duration, followed by centrifugation at a speed of $3500 \mathrm{rpm}$ during $45 \mathrm{~min}$ (VWR Mega Star 1.6, VWR International bvba, Leuven, Belgium). Then, the samples were subsequently stored at $-80^{\circ} \mathrm{C}$ freezer for complete solidification before freeze drying by a freeze-dryer (CHRIST Gamma 2-16 LSCplus, Martin Christ $\mathrm{GmbH}$, Osterode am Harz, Germany). The obtained dry mass was weighted immediately, which is indicated as $W_{\text {dry mass, }}$ and the yield of the total dry mass was calculated by $\left(W_{\text {dry mass }} / 70\right) \times 100 \%$.

\subsubsection{Traditional Magnetic Stirring Method}

For the extraction, $70 \mathrm{~g}$ flax seeds were put into $700 \mathrm{~mL}$ tap water one hour before the extraction. Then, the extraction temperature was set to room temperature (RT), 40 and $70{ }^{\circ} \mathrm{C}$, respectively with a stirrer speed of $400 \mathrm{rpm}$. The extraction period was set to 1, 3, 6, 20 and $48 \mathrm{~h}$, respectively.

\subsubsection{Ultrasonic Assisted-Extraction}

In regard to $\mathrm{UAE}$, a two stages extraction program was conducted. In the first stage, around $70 \mathrm{~g}$ flax seeds were put into $700 \mathrm{~mL}$ tap water one hour before the extraction process, then the treatment was conducted during one period of 30 and $75 \mathrm{~min}$, respectively. In the second stage, another same amount $(700 \mathrm{~mL})$ of tap water was subsequently added into the extraction container after removal of the previous solution, and the successive extraction was conducted during the same period as the previous one.

\subsection{Flaxseed Gum Characterization}

\subsubsection{Determination of Sugar and Protein Contents}

The neutral sugar composition was determined by colorimetric methods [14,15]. The acidic sugar content was calculated as milligrams of D-galacturonic acid per milligrams of the mucilage [16]. The protein content of each dry mass was tested according to the principle of the bicinchoninic acid (BCA) [17]. Four concentrations (10, 7.5, 5 and $2.5 \mathrm{mg} / \mathrm{mL}$ ) of each mucilage sample was prepared, and the tests of each sample were all performed in triplicate.

\subsubsection{NMR Spectroscopy}

All NMR experiments were recorded on a Bruker Avance III spectrometer (Billerica, MA, USA) at $400 \mathrm{MHz}(9.4 \mathrm{~T})$, equipped with a multinuclear z-gradient BBFO probe head capable of producing magnetic field pulse gradients in the z-direction of $48.15 \mathrm{G} . \mathrm{cm}^{-1}$. In standard experiments, the probe temperature was maintained at $298 \mathrm{~K}$ and $\mathrm{D}_{2} \mathrm{O}$ was used as solvent. 


\subsubsection{Scanning Electron Microscopy (SEM)}

The surface morphology of mucilage samples was characterized by scanning electron microscopy (SEM) under high vacuum with a field emission SEM instrument (JSM-7100F, Tokyo, Japan). Around $250 \mathrm{mg}$ mucilage samples were first dissolved into around $10 \mathrm{~mL}$ distilled water and then the solution was transferred onto a petri dish to allow the evaporation of water, the obtained film was subsequently collected and used for the SEM analysis, and the film sample were coated with a thin (around $10 \mathrm{~nm}$ ) chromium before observation.

\subsubsection{Differential Scanning Calorimetry (DSC)}

The differential scanning calorimetry (DSC) thermograms were recorded on a DSC Q1000 DSC instrument (TA instruments, New Castle, PA, USA). An indium standard was used for the calibration and nitrogen was used as the purge gas. The sample was heated from room temperature to $300{ }^{\circ} \mathrm{C}$ at a heating rate of $10^{\circ} \mathrm{C} / \mathrm{min}$. SDT Q600 (TA Instruments, New Castle, Pennsylvania, United States) was used for thermogravimetric analysis (TGA). Around 4-8 mg samples were scanned from 20 to $800^{\circ} \mathrm{C}$ at a heating rate of $10^{\circ} \mathrm{C} / \mathrm{min}$ in the presence of $100 \mathrm{~mL} / \mathrm{min}$ nitrogen flow.

\subsubsection{Thermal Gravimetric Analysis (TGA)}

Thermal decomposition was quantified by the determination of energy activation $\left(E_{a}\right)$ using Broido method [18]. The degradation process of polymer, and a fortiori mixture of polysaccharides, includes various sequences of reaction which depend on the nature of compounds and their intermolecular bonds. Insofar as the pyrolysis give chars and volatiles, the progress of decomposition can be done from thermogravimetric analysis. For an isothermal experiment, the thermal decomposition is given by [19]:

$$
-\frac{d(1-\alpha)}{d t}=k f(1-\alpha)^{n}
$$

where $f$ is a function representative of reaction mechanisms, $n$ is the reaction order, $k$ is the rate constant according to the Arrhenius equation and $\alpha$ is the degree of conversion expressed as follow:

$$
\alpha=\frac{W_{e}}{W_{0}}
$$

where $W_{e}$ is the mass loss by volatilization and $W_{0}$ is the initial mass. Thus, the integration and rearrangement of Equation (1) gives Broido equation:

$$
\ln \left[\ln \left(\frac{1}{1-\alpha}\right)\right]=\frac{-E_{a}}{R T}+\text { constant }
$$

where $R$ is the universal gas constant, the slope of $\ln \left[\ln \left(\frac{1}{1-\alpha}\right)\right]$ vs. $1 / T$ corresponds to $-E_{\mathrm{a}} / R$ and can provide the value of $E_{\mathrm{a}}$.

\section{Results and Discussion}

\subsection{Traditional Stirring Extraction}

The yield of mucilage, protein content and $\mathrm{pH}$ values of the gum solution extracted at $25^{\circ} \mathrm{C}, 40^{\circ} \mathrm{C}$ and $70^{\circ} \mathrm{C}$ with varying extraction duration $(1,3,6,20$ and $48 \mathrm{~h})$ are listed in Table 1 . According to the results, both the protein content and yield of mucilage increase along the extraction duration whatever the temperature. As shown in Table 1, the flaxseed gum yield ranges from $3.2 \%$ to $6.4 \%$ at $25^{\circ} \mathrm{C}$ and from $3.9 \%$ to $19.9 \%$ at $40{ }^{\circ} \mathrm{C}$ of seed weight, respectively. Compared to the literature, these values are in a higher range but of the same order to those previously reported [20]. The linearity of extraction yield against temperature between $25^{\circ} \mathrm{C}$ and $40^{\circ} \mathrm{C}$ highlights the temperature effect on the matter diffusion within the seed. However, the operating mode at $70^{\circ} \mathrm{C}$ leads to a drastic raise of yield from the first hour reaching to $8.4 \%$, subsequently exhibits a weaker increase of yields compared to other extraction temperature which is probably due to a partial degradation of flaxseed gum during the extraction. 
Table 1. Yield (\%), protein content (\%) and $\mathrm{pH}$ values of flaxseed extracted from traditional stirring extraction.

\begin{tabular}{cccccccccc}
\hline $\begin{array}{c}\text { Extraction } \\
\text { Time (h) }\end{array}$ & \multicolumn{2}{c}{ Yield of Total Dry Mass (\%) } & \multicolumn{3}{c}{ Protein Content (\%) } & & pH \\
\hline & $\mathbf{2 5}{ }^{\circ} \mathbf{C}$ & $\mathbf{4 0}{ }^{\circ} \mathbf{C}$ & $\mathbf{7 0}{ }^{\circ} \mathbf{C}$ & $\mathbf{2 5}{ }^{\circ} \mathbf{C}$ & $\mathbf{4 0}{ }^{\circ} \mathbf{C}$ & $\mathbf{7 0}{ }^{\circ} \mathbf{C}$ & $\mathbf{2 5}{ }^{\circ} \mathbf{C}$ & $\mathbf{4 0}{ }^{\circ} \mathbf{C}$ & $\mathbf{7 0}{ }^{\circ} \mathbf{C}$ \\
\hline $\mathbf{1}$ & $3.2 \pm 0.1$ & $3.9 \pm 0.2$ & $8.4 \pm 0.5$ & $7.0 \pm 0.3$ & $9.4 \pm 1.2$ & $10.2 \pm 0.2$ & $10.1 \pm 0.2$ & $9.9 \pm 0.1$ & $7.8 \pm 0.4$ \\
$\mathbf{3}$ & $3.5 \pm 0.2$ & $4.7 \pm 0.4$ & $10.5 \pm 0.7$ & $7.4 \pm 1.0$ & $10.4 \pm 0.3$ & $15.0 \pm 0.8$ & $10.1 \pm 0.1$ & $9.5 \pm 0.3$ & $7.0 \pm 0.1$ \\
$\mathbf{6}$ & $4.0 \pm 0.3$ & $5.7 \pm 0.3$ & $10.9 \pm 0.9$ & $9.8 \pm 1.6$ & $12.8 \pm 0.6$ & $16.2 \pm 0.7$ & $8.0 \pm 0.1$ & $5.7 \pm 0.2$ & $6.9 \pm 0.4$ \\
$\mathbf{2 0}$ & $5.8 \pm 0.2$ & $8.7 \pm 0.6$ & $11.8 \pm 0.6$ & $12.3 \pm 0.3$ & $16.1 \pm 1.9$ & $12.9 \pm 0.6$ & $6.7 \pm 0.2$ & $5.4 \pm 0.2$ & $6.6 \pm 0.3$ \\
$\mathbf{4 8}$ & $6.4 \pm 0.4$ & $19.9 \pm 1.3$ & $12.3 \pm 1.1$ & $20.3 \pm 2.8$ & $16.1 \pm 0.6$ & $17.6 \pm 1.2$ & $7.1 \pm 0.1$ & $4.8 \pm 0.1$ & $6.3 \pm 0.2$ \\
\hline
\end{tabular}

The yield of protein extracted follows a similar trend to gum extraction, which exhibits an increase as a function of both time and temperature. This phenomenon could be assigned to water molecules, in particular their high probability to be able to cross one and several layers and reach the inside layer "endosperm" and therefore transport water soluble proteins together with the polysaccharides. Furthermore, in order to manage the extraction operation, we have monitored the $\mathrm{pH}$ values. These results show an increase of acidity with increasing the extraction duration regardless of the operating temperature.

\subsection{Ultrasonic Assisted Extraction (UAE)}

The mucilage results obtained by UAE with varying extraction duration were summarized in Table 2. According to the results of the first extraction, the yield of total dry mass, yield of mucilage and protein contents increase with increasing the extraction duration, while the $\mathrm{pH}$ value decreases slightly and then keeps constant at the same time.

Table 2. Yield (\%), protein content (\%) and $\mathrm{pH}$ values of flaxseed gum from ultrasonic-assisted extraction.

\begin{tabular}{ccccc}
\hline $\begin{array}{c}\text { Extraction Period } \\
\text { (min) }\end{array}$ & $\begin{array}{c}\text { N of Successive } \\
\text { Extraction }\end{array}$ & $\begin{array}{c}\text { Yield of Total Dry } \\
\text { Mass (\%) }\end{array}$ & $\begin{array}{c}\text { Protein Content } \\
\mathbf{( \% )}\end{array}$ & pH \\
\hline \multirow{2}{*}{30} & 1 & $7.5 \pm 0.3$ & $10.5 \pm 1.2$ & 8.9 \\
& 2 & $6.7 \pm 0.3$ & $20.3 \pm 1.4$ & 7.9 \\
75 & 1 & $10.9 \pm 0.6$ & $20.3 \pm 2.2$ & 6.8 \\
& 2 & $4.9 \pm 0.1$ & $31.2 \pm 1.1$ & 7.8 \\
\hline
\end{tabular}

After 30 min of ultrasonic irradiation, the yield of mucilage is close to that obtained from the traditional method at the extraction temperature $70^{\circ} \mathrm{C}$ during one hour of extraction. This observation has demonstrated the enhanced efficiency of the ultrasonic assisted extraction compare to the traditional magnetic stirring one. The protein content is in general higher compare to those of the samples obtained by traditional magnetic stirring method for the similar extraction duration. In particular, the protein content of the successive extraction conducted in the second stage is much (around two times) higher than those obtained from the first extraction stage. No significant change of $\mathrm{pH}$ was observed during ultrasonic assisted extraction. The results indicate that the increase of protein content in the extracted mixtures was not involved in the decrease of the $\mathrm{pH}$ during thermic extraction. This result further supports that other acidic component might be extracted with increasing the extraction duration of the traditional magnetic stirring method.

\subsection{Determination of Sugar Contents}

In order to investigate the evolution of $\mathrm{pH}$ value, we further analyzed the composition of the acidic and neutral sugar in the mucilage samples extracted at different temperatures and extraction durations (Table 3). According to the results, we can notice that the acidic and neutral sugar concentration in the mucilage samples decrease with increasing both the extraction duration and extraction temperature. This phenomenon has already been observed [7,9] and was attributed to 
the degradation of polysaccharide fractions at higher temperature. These observations are consistent with UAE experiments, which are known to enhance polymer degradation [21]. The examination of the neutral and acidic fraction shows lower values compared to those of the literature, indicating that neutral polysaccharide is less sensitive to extraction temperatures. In the case of stirring mode, the ratio of neutral fraction (NF) to acidic fraction (AF) tends to decrease regardless of the application temperature when the extraction duration is more than $20 \mathrm{~h}$, while in the case of $\mathrm{UAE}$, it increases with the successive extraction, which is probably due to the oxidative effects of free radical species on the acidic polysaccharides [22].

Table 3. Acidic and neutral sugar contents of the selected extraction samples.

\begin{tabular}{|c|c|c|c|c|}
\hline $\begin{array}{l}\text { Extraction } \\
\text { Mode }\end{array}$ & $\begin{array}{l}\text { Extraction } \\
\text { Time (h) }\end{array}$ & $\begin{array}{c}\text { Acidic Fraction (AF) } \\
(\%)\end{array}$ & $\begin{array}{c}\text { Neutral Fraction (NF) } \\
(\%)\end{array}$ & NF/AF \\
\hline \multirow{3}{*}{$25^{\circ} \mathrm{C}$} & 1 & 16.3 & 61.2 & 3.8 \\
\hline & 20 & 15.3 & 60.6 & 4.0 \\
\hline & 48 & 14.3 & 46.7 & 3.3 \\
\hline \multirow{3}{*}{$40{ }^{\circ} \mathrm{C}$} & 1 & 16.1 & 54.4 & 3.4 \\
\hline & 20 & 10.5 & 41.3 & 3.9 \\
\hline & 48 & 8.4 & 24.4 & 2.9 \\
\hline \multirow{3}{*}{$70{ }^{\circ} \mathrm{C}$} & 1 & 8.9 & 42.8 & 4.8 \\
\hline & 20 & 9.9 & 56.4 & 5.7 \\
\hline & 48 & 9.0 & 45.2 & 5.0 \\
\hline \multirow{4}{*}{ UAE } & 0.5 & 19.3 & 38.9 & 2.0 \\
\hline & $2 * 0.5$ & 9.4 & 34.8 & 3.7 \\
\hline & 1.25 & 15.7 & 39.6 & 2.5 \\
\hline & $2 * 1.25$ & 8.9 & 36.4 & 4.1 \\
\hline
\end{tabular}

* indicates a successive extraction.

The overall $\mathrm{pH}$ results indicate that the decrease of the $\mathrm{pH}$ value is not caused by the increase of the acidic sugar concentrations, which underlines that other acidic component might be extracted over the extraction procedures.

\subsection{NMR Characterization}

The NMR analysis was subsequently conducted in order to investigate the compounds extracted during the different operating modes. Thus the ${ }^{1} \mathrm{H}$ and ${ }^{13} \mathrm{C}$ NMR spectra of flaxseed mucilage extracted by traditional magnetic stirring after $1 \mathrm{~h}$ and $48 \mathrm{~h}$ (extracts obtained after $20 \mathrm{~h}$ were presented in Supplementary Material) and by UAE method were presented in Figures 1 and 2, respectively. According to previously reported literatures $[23,24]$, the ${ }^{1} \mathrm{H}$ NMR spectra present three regions ranging from 0 to 3, 3-6 and 6-9 ppm, which can be principally assigned to the protons of the amino acids and carboxylic acids, carbohydrates and phenolic derivatives, respectively (Figure 1a). In a first observation, we notice that the identified parts of spectra can be quite different according to extraction procedure. The analysis of ${ }^{1} \mathrm{H}$ NMR data at $25^{\circ} \mathrm{C}$ and $40{ }^{\circ} \mathrm{C}$ for one hour of extraction show quite similar spectra while with the increase of temperature to $70{ }^{\circ} \mathrm{C}$, the presence of more amino and carboxylic acids as well as phenolic derivatives has been detected. This observation is consistent with the analysis based on $\mathrm{pH}$ values that the extracted solutions show decreased $\mathrm{pH}$ value with increasing the temperature (Table 1). According to Figure 1a, with increasing the extraction duration from $1 \mathrm{~h}$ to $48 \mathrm{~h}$ at $25^{\circ} \mathrm{C}$, we can observe the appearance of a singlet at $8.37 \mathrm{ppm}$ suggesting the presence of phenolic acids also called lignans, which are widely distributed in plants and have numerous beneficial effects on human health $[25,26]$. In general, two classes of phenolic acids can be distinguished: derivatives of benzoic acid and derivatives of cinnamic acid. The hydroxycinnamic acids, consisting mainly of $p$-coumaric, caffeic, ferulic and sinapic acids are more common than the hydroxybenzoic acids. These acids being rarely found in free form, explains the absence of the absorption peaks 
corresponding to the proton of carboxylic acid in the range of 10-13 ppm [27]. Furthermore, it has also been reported that one of the particularities of the flaxseed is that lignans, such as secoisolariciresinol diglucoside (SDG), are ester-linked via hydroxymethylglutarate (HMG) binding with the carbohydrates to form a macromolecular complex [28-30]. Therefore, the absorption peak at $1.25 \mathrm{ppm}$ could be attributed to the absorption of the methyl group of some lignans derivatives extracted from flaxseed. Otherwise, according to the ${ }^{13} \mathrm{C}$ NMR spectra shown in Figure $1 \mathrm{~b}$, the signature resonance of the ester between 160-190 ppm as well as alkyl group at around $20 \mathrm{ppm}$ are detected for the sample with extraction duration being $48 \mathrm{~h}$, further supporting that the extracted lignan macromolecules are mainly ester-linked with the polysaccharides via HMG bonding. This result is also in accordance with previous analysis based on the $\mathrm{pH}$ value, which further supports that the slight decrease of the $\mathrm{pH}$ value with increasing the extraction duration for the samples extracted at room temperature is more likely to be caused by the extraction of the lignans while not the acidic sugars of mucilage.

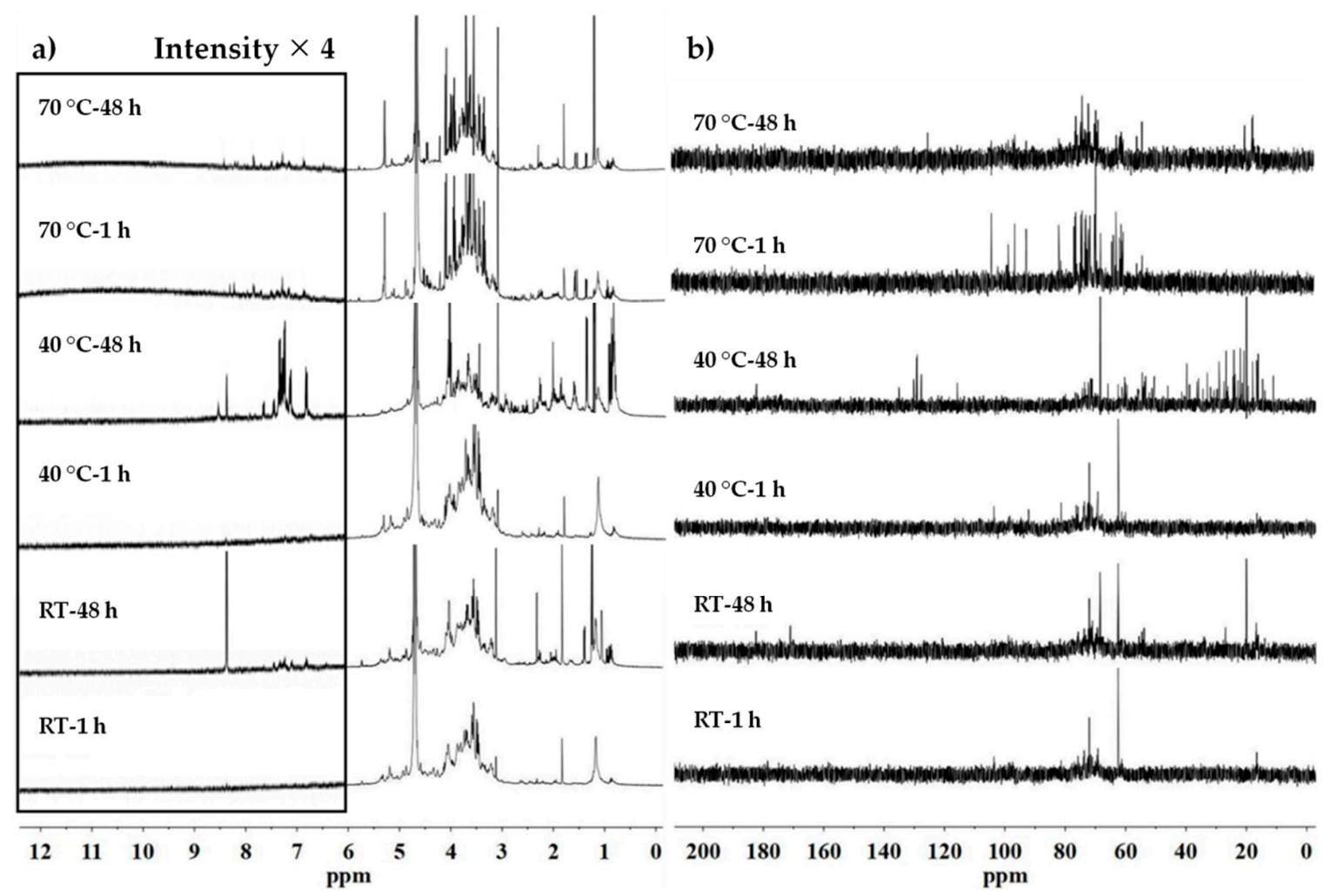

Figure 1. ${ }^{1} \mathrm{H}$ (a) and ${ }^{13} \mathrm{C}(\mathbf{b}) \mathrm{NMR}$ spectra of flaxseed mucilage extracted by magnetic stirring method depending on time and temperature. 

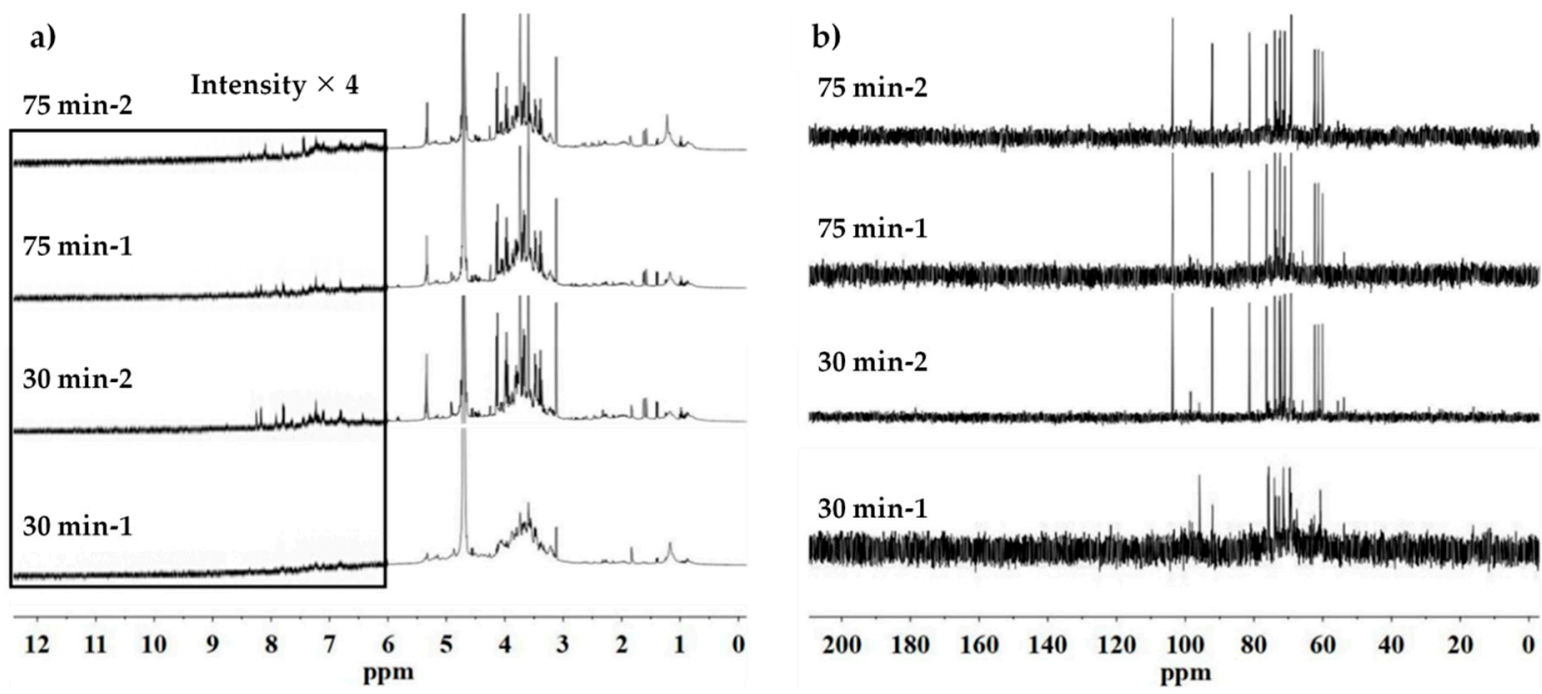

Figure 2. ${ }^{1} \mathrm{H}(\mathbf{a})$ and ${ }^{13} \mathrm{C}(\mathbf{b}) \mathrm{NMR}$ spectra of flaxseed mucilage extracted by UAE.

After $48 \mathrm{~h}$ of extraction, the resonance of aliphatics and aromatics are mainly predominant for the samples extracted at $40{ }^{\circ} \mathrm{C}$. The aromatic parts reveal peaks from SDG elements as well as from other phenolic compounds, such as $p$-coumaric acid and ferulic acid moieties [31,32]. This is also consistent with the signals corresponding to aromatic carbons in the range of 100-140 ppm and carbonyl group of esters in the range of 160-190 ppm (Figure 1b). Thus, the presence of more phenolic absorption peaks and enhanced peak intensities indicate that more lignan macromolecules can be extracted with long extraction duration at $40{ }^{\circ} \mathrm{C}$ compare to room temperature. At $70{ }^{\circ} \mathrm{C}$ very weak absorbance peaks on ${ }^{1} \mathrm{H}$ NMR spectra in the range of 6-9 ppm could be observed though the intensity of the absorption peak corresponding to the methyl group of HMG at $1.25 \mathrm{ppm}$ increases concomitantly with the extraction duration. On the corresponding ${ }^{13} \mathrm{C}$ NMR spectra, the alkyl absorption of HMG is detected for the sample with the extraction duration being $48 \mathrm{~h}$, while no absorption corresponding to the ester bond could be detected. Knowing that the degradation of the lignans in flax seeds was observed at $100{ }^{\circ} \mathrm{C}[30]$, it is reasonable to suggest that a lengthy extraction at $70{ }^{\circ} \mathrm{C}$ can cause the degradation of lignan molecules and therefore only very weak absorption traces can be detected for the samples extracted at this temperature. This result is also in agreement with the analysis based on the $\mathrm{pH}$ value since the presence of the lignans in the sample just after one-hour extraction at $70{ }^{\circ} \mathrm{C}$ can be considered to be the reason of a low $\mathrm{pH}$ value, and occurrence of degradations of phenolic compounds explains the slight drop of the $\mathrm{pH}$ value with increasing the extraction duration at this extraction temperature.

The ${ }^{1} \mathrm{H}$ and ${ }^{13} \mathrm{C}$ NMR spectra of the samples obtained by two stages UAE with the extraction duration being $30 \mathrm{~min}$ and $75 \mathrm{~min}$ are shown in Figure 2. According to the results, only just a few traces of absorption spectra corresponding to lignan macromolecules can be observed indicating these compounds can be extracted together with the gum in a short time under sonication though SDG compounds are located in the parenchymatic cells below the mucilage cells $[33,34]$. This can be assigned to the impact of acoustic cavitation. In regard to the $\mathrm{pH}$ value (Table 2), we can explain that the slight increase of acidity of UAE30min-2 compare to that of UAE30min- 1 as shown in Table 2 is due to the presence of lignan traces during the second stage of extraction. It is worth to note that the $\mathrm{pH}$ value of UAE75min-2 increases slightly compare to that of the UAE75min-1, which indicates a probable degradation of extracted lignans by $\mathrm{OH}$-radicals generated under acoustic cavitation. Indeed, it has been shown that a presence of $5 \%$ to $11 \%$ of $\cdot \mathrm{OH}$ benzaldehyde derivatives could be produced from hydroxycinnamic acids [35], which might be responsible to the increase of medium basicity. Moreover, another effect of ultrasound irradiation is to extract high concentration of protein which are located in the endosperm of flaxseed. 
Otherwise, with referring to the ${ }^{13} \mathrm{C}$ NMR spectra, the samples extracted by UAE exhibit very characteristic absorption peaks of the standard reference sugars (see Supplementary Data) compared to samples obtained by traditional magnetic stirring method. It indicates the possibilities of polysaccharides of mucilage might be degraded into monosaccharide fractions by ultrasound application. Further discussions concerning this point will be conducted in the physical analysis part.

\subsection{SEM Analysis}

In order to obtain general information about the surface morphology of the extracted samples we have conducted SEM analysis on flaxseed (Figure 3). The flaxseed gum is located in the mucous epidermis under the cuticle layer of seed [8]. The examination of unsoaked seed shows the smooth surface of filled epidermis integument pentagonal cells (Figure 3A). At room temperature, the gum extraction and the mass transfer of polysaccharide toward the medium cause the digging of cells viewed by the appearance of the intercellular walls (Figure 3B) as already described elsewhere [36,37]. As we can see on SEM image, the increase of extraction yield induces deeper digging and the edge of the cells is no longer round but more abrupt (Figure 3C). The UAE, which gives a high gum and protein extraction yield, leads to further modification of external seed surface since the cuticle layer seems to have lost of flatness (Figure 3D). These observations highlight the mechanical effect of acoustic cavitation induced by the asymmetric collapse of cavitation bubbles, leading to formation of microjets and thus impacting the flaxseed integument.
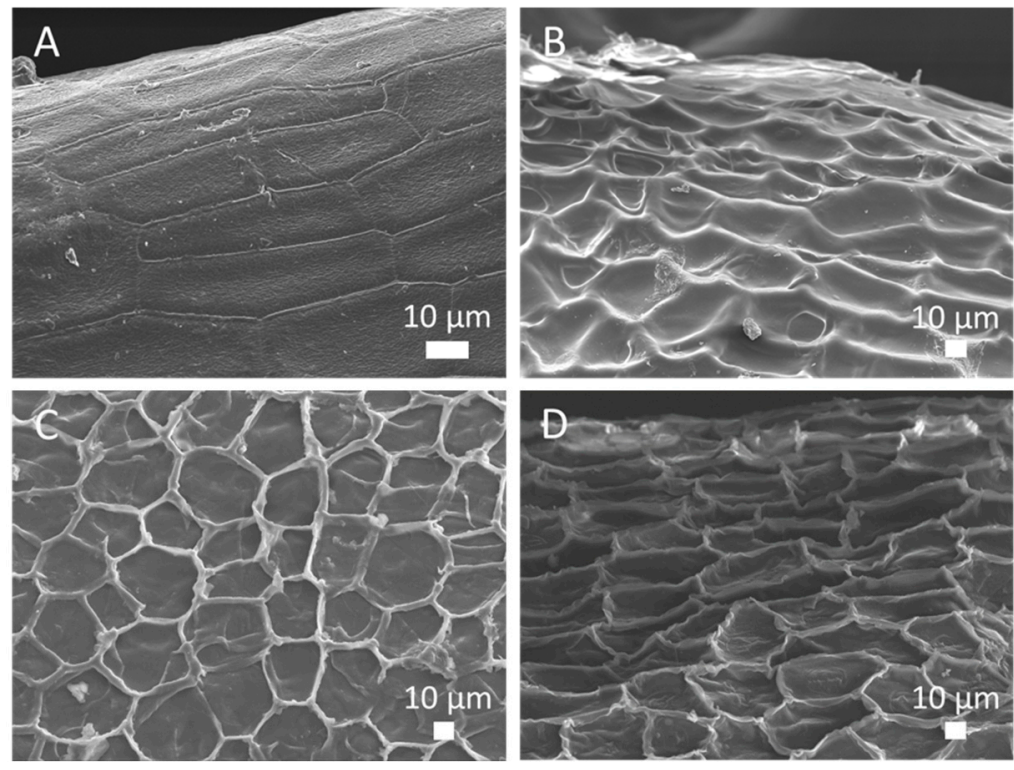

Figure 3. SEM images of surface seeds; unsoaked (A) and after extraction during $1 \mathrm{~h}$ at $25{ }^{\circ} \mathrm{C}(\mathbf{B}), 40{ }^{\circ} \mathrm{C}$ (C) and UAE75min-1 (D).

Figure 4 shows SEM images of representative textures from extracted samples. Indeed, according to the extraction mode, the thin film of flaxseed gum can exhibit a relative homogenous texture, globular aggregates as well as columnar aggregates as shown in Figure 4A-E respectively. The smooth texture (Figure $4 \mathrm{~A}$ ) was obtained in soft extraction conditions i.e., at room temperature (regardless of the extraction duration) and at $40^{\circ} \mathrm{C}$ below $6 \mathrm{~h}$. In these conditions, thin films exhibit nanometric spherical particles (100 to $300 \mathrm{~nm}$ ) due to the formation of polysaccharide aggregates. The examination of Table 1 allows to correlate the increasing size of aggregates with the decreasing of $\mathrm{pH}$ value due to release of hydroxycinnamic acids to give numerous micrometric size spherical particles (Figure 4B). This $\mathrm{pH}$-dependence effect of gelation of flaxseed gum is consistent with previous work since it has been already shown that the gel strength dropped down with decreasing $\mathrm{pH}$ values [38]. This is due to synergic coagulation between polysaccharide chains and protein taking place in acidic medium [39,40]. 
Indeed, it has been demonstrated when $\mathrm{pH}$ is higher than $\mathrm{pH}_{\mathrm{i}}$ (isoelectric point of the protein is $\mathrm{pH} 4.4$ ) the net charge of the protein becomes negative resulting electrostatic repulsive forces between protein molecules and polysaccharides. At low $\mathrm{pH}$ values, the compatibility between polysaccharides and proteins is effective and leads to the formation of aggregates. Thus, with combination to the NMR analysis, it is more reasonable to suggest the macromolecule complexes that formed by the lignan molecules ester-bonded to polysaccharides associated to proteins are responsible to the formation of globular aggregates. However, it is interesting to note that the extracts show a mixed particle size depending on extraction duration at $70{ }^{\circ} \mathrm{C}$ since globular particles are more numerous when the extraction is extended, which also corresponds to the increase of phenol diglucoside concentration (Figure 4C). We attribute it to be the positive effect of polyols and sugars against the denaturation of proteins which tends to increase the thermal stability of these macromolecules [41].
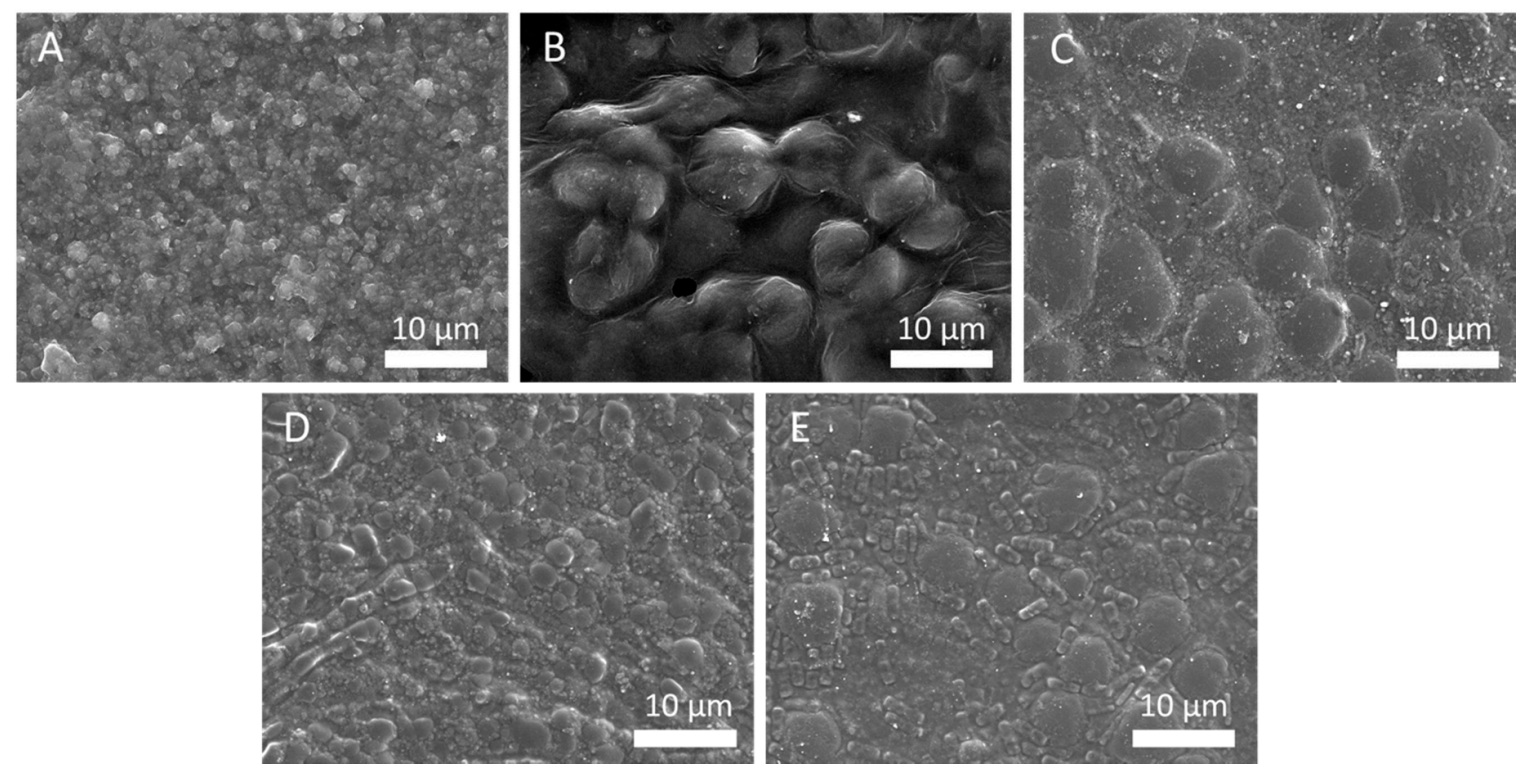

Figure 4. SEM images of mucilage samples extracted at $25{ }^{\circ} \mathrm{C}$ over $1 \mathrm{~h}(\mathrm{~A})$, at $40{ }^{\circ} \mathrm{C}$ over $48 \mathrm{~h}(\mathbf{B})$, at $70{ }^{\circ} \mathrm{C}$ over $48 \mathrm{~h}(\mathbf{C})$ and UAE30min-1 (D), UAE30min-2 (E).

SEM images of UAE flaxseed gum (Figure 4D,E) reveals globular aggregates for the whole sonicated samples associated to columnar aggregates whose maximal concentration is reached for longer duration of acoustic irradiation (Figure 4E). This rod-like molecular organization is characteristic of amphitropic liquid crystal which can be obtained from amphiphilic block-copolymer based on glucosides [42]. However, these hierarchical self-assemblies can also come from cyclopeptides who present the adequate ratio between hydrophilic and hydrophobic blocks such as cyclolinopeptides, which are found in flaxseeds [43]. Indeed, it has been shown that sonication is able to increase protein solubility and modify surface hydrophobicity which could favor the formation of supramolecular complexes [44]. These observations imply the nature of the amphiphilic mesogen carbohydrate structures and also the selective extraction to give their specific arrangements. Further investigations will have to be led especially in order to elucidate the potential production of mesogen compounds from flaxseed under sonication. It might be due to that the acoustic cavitation causes the partial degradation of the macromolecule complexes associated to amphiphilic species whose self-assembly forms specific networks.

\subsection{TGA Analysis}

TGA analysis can estimate the thermal stability of a material by measuring the weight loss against the temperature. Figure 5a-e shows TGA and DTG curves of the mucilage sample extracted at room temperature, $40{ }^{\circ} \mathrm{C}$ and $70{ }^{\circ} \mathrm{C}$ after $1 \mathrm{~h}$ and $48 \mathrm{~h}$ as well as gum obtained by UAE with extraction 
duration being 30 and $75 \mathrm{~min}$, respectively. Thermograms exhibit characteristic thermal decompositions of natural gum [45]. The first step of decomposition is related to an initial weight loss due to moisture evaporation $(5-11 \%)$ between $30-130^{\circ} \mathrm{C}$. It can be noted that the loss of water decreases when increasing the extraction temperature as well as the sonication duration. This indicates a reduction of hydrophilic character of flaxseed gum, which is consistent with the formation of molecular aggregates observed in SEM experiments. The second stage of decomposition appears at $200-350{ }^{\circ} \mathrm{C}$ and was due to thermal degradation of both polysaccharides and proteins according to different mechanisms (dehydration, depolymerization or pyrolytic decomposition). After $1 \mathrm{~h}$ of extraction at room temperature and $40{ }^{\circ} \mathrm{C}$, the decomposition presents a main peak while in other extraction modes a second process of degradation appears causing either the widening of the transition or appearance of a second band.
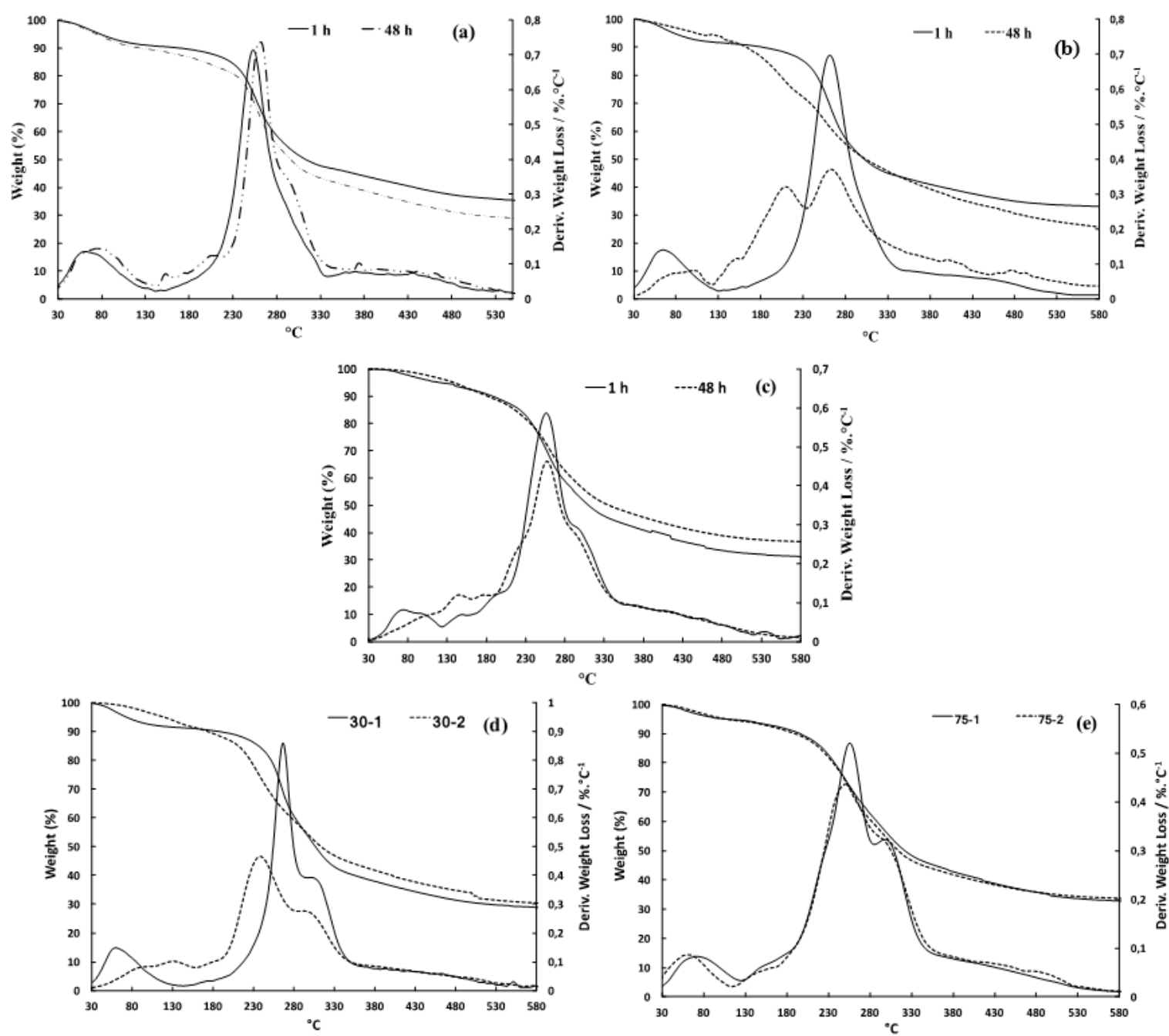

Figure 5. TGA/DTG thermograms of flaxseed gums extracted during $1 \mathrm{~h}$ and $48 \mathrm{~h}$ at $25^{\circ} \mathrm{C}$ (a), at $40{ }^{\circ} \mathrm{C}(\mathbf{b})$, at $70{ }^{\circ} \mathrm{C}(\mathbf{c})$ and by UAE during $30 \mathrm{~min}(\mathbf{d})$ and $75 \mathrm{~min}(\mathbf{e})$ for stages 1 and 2.

For the flaxseed gum samples extracted by UAE, a shoulder peak is detected for all the samples, indicating the higher protein content in the samples extracted by this method. For the samples extracted by traditional magnetic stirring method, the shoulder peak corresponding to proteins is not obvious to be differentiated for the sample extracted at room temperature after $1 \mathrm{~h}$ of extraction, probably because the presented amount of proteins (around 7\% according to Table 1) is not significant enough for this peak to be appeared in the TGA curve. This result demonstrates that the TGA analysis can also be one of the methods to evaluate the general protein content presented in the extracted mucilage samples. 
The $E_{\mathrm{a}}$ calculated from Broido equation plot (Equation (3)) are shown in Tables 4 and 5 for thermal methods and UAE, respectively. The thermal decomposition experiments gave low activation energies in the range of $23.9-45.9 \mathrm{KJ} / \mathrm{mol}$.

Table 4. TGA/DTG data of flaxseed gums extracted by magnetic stirring methods.

\begin{tabular}{|c|c|c|c|c|c|c|}
\hline $\begin{array}{l}\text { Extraction } \\
\text { Temperature }\end{array}$ & $\begin{array}{l}\text { Extraction } \\
\text { Time (h) }\end{array}$ & $\begin{array}{c}\mathbf{N}^{\circ} \text { of } \\
\text { Decomposition } \\
\text { Stage }\end{array}$ & $\begin{array}{c}\text { Temperature } \\
\text { Range }\left({ }^{\circ} \mathrm{C}\right)\end{array}$ & $\begin{array}{c}\text { DTG } \\
\text { Maxima } \\
\left({ }^{\circ} \mathrm{C}\right)\end{array}$ & $\begin{array}{l}\text { \%wt. } \\
\text { Loss }\end{array}$ & $\begin{array}{c}\text { Activation } \\
\text { Energy } \\
(\mathrm{kJ} / \mathrm{mol})\end{array}$ \\
\hline \multirow{4}{*}{$25^{\circ} \mathrm{C}$} & \multirow{2}{*}{1} & 1 & $24.7-141.3$ & 61.6 & 9.3 & - \\
\hline & & 2 & $152.4-338.5$ & 253.1 & 43.5 & 43.6 \\
\hline & \multirow{2}{*}{48} & 1 & $25.9-142.9$ & 73.0 & 10.7 & - \\
\hline & & 2 & 161.9-357.2 & 259.3 & 46.9 & 38.0 \\
\hline \multirow{4}{*}{$40{ }^{\circ} \mathrm{C}$} & \multirow{2}{*}{1} & 1 & $24.7-132.0$ & 64.9 & 8.4 & - \\
\hline & & 2 & $151.4-357.2$ & 261.5 & 48.0 & 45.9 \\
\hline & \multirow{2}{*}{48} & 1 & $24.7-126.8$ & 65.2 & 5.7 & - \\
\hline & & 2 & 133.9-358.0 & $220.2 ; 260.7$ & 51.7 & 23.9 \\
\hline \multirow{4}{*}{$70{ }^{\circ} \mathrm{C}$} & \multirow{2}{*}{1} & 1 & $27.5-130.4$ & 69.2 & 5.3 & - \\
\hline & & 2 & $146.9-370.3$ & 257.7 & 52.0 & 36.1 \\
\hline & \multirow{2}{*}{48} & 1 & - & - & - & - \\
\hline & & 2 & $190.5-360.4$ & 259.4 & 41.7 & 29.0 \\
\hline
\end{tabular}

Table 5. TGA/DTG data of flaxseed gums extracted by UAE.

\begin{tabular}{ccccccc}
\hline $\begin{array}{c}\text { Extraction } \\
\text { Time (min) }\end{array}$ & $\begin{array}{c}\text { Extraction } \\
\text { Stage }\end{array}$ & $\begin{array}{c}\mathbf{N}^{\circ} \text { of } \\
\text { Decomposition } \\
\text { Stage }\end{array}$ & $\begin{array}{c}\text { Temperature } \\
\text { Range }\left({ }^{\circ} \mathbf{C}\right)\end{array}$ & $\begin{array}{c}\text { DTG } \\
\text { Maxima } \\
\left({ }^{\circ} \mathbf{C}\right)\end{array}$ & $\begin{array}{c}\text { \%wt. } \\
\text { Loss }\end{array}$ & $\begin{array}{c}\text { Activation } \\
\text { Energy } \\
(\mathbf{k J} / \mathbf{m o l})\end{array}$ \\
\hline \multirow{3}{*}{30} & 1 & 1 & $24.7-143.3$ & 59.2 & 8.7 & - \\
& 2 & 1 & $152.2-379.4$ & 266.3 & 52.9 & 40.7 \\
\hline \multirow{2}{*}{2} & 2 & $28.3-160.3$ & 135.7 & 8.4 & - \\
& \multirow{2}{*}{1} & 1 & $25.9-132.0$ & 74.1 & 5.7 & - \\
& \multirow{2}{*}{1} & 2 & $135.2-381.0$ & 262.2 & 52.1 & 34.2 \\
\hline \multirow{2}{*}{2} & 1 & $24.2-121.1$ & 61.6 & 5.2 & - \\
& 2 & 2 & $135.2-390.3$ & 255.4 & 52.3 & 33.8 \\
\hline
\end{tabular}

It can be seen that flaxseed gums extracted at room temperature and $40{ }^{\circ} \mathrm{C}$ during one hour have the highest $E_{\mathrm{a}}$. These results are consistent with thermal stabilities deduced from DSC curves, which will be presented in next section. The hardening of extraction conditions by raise the temperature, lengthening the duration as well as the use of acoustic cavitation cause the decrease of $E_{\mathrm{a}}$. This finding is in agreement with NMR data which shows a partial degradation of extracted natural compounds and monomer units induced by UAE.

\subsection{DSC Analysis}

Figure 6 shows the thermal heating curves of the samples extracted by both ultrasonic assisted and traditional extraction methods. All thermograms exhibit endothermic transitions whose amplitudes vary depending on molecular mixtures induced by modulation of extraction parameters. According to Figure $5 \mathrm{a}, \mathrm{b}$, the main melting peaks of both the samples extracted after 1 and $48 \mathrm{~h}$ at room temperature are at around $213-214{ }^{\circ} \mathrm{C}$. The melting peak of the sample extracted after $48 \mathrm{~h}$ is narrower and sharper compared to that obtained after $1 \mathrm{~h}$, on which a significant shoulder in the range of 140 and $190{ }^{\circ} \mathrm{C}$ can be observed while is almost invisible after a long extraction. Better thermal stability and more homogenous character expand along with the increase of extraction time at room temperature, probably 
due to the presence of lignan derivatives, which stabilizes the macromolecular mixture to form stable supramolecular aggregates (Figure 6b).
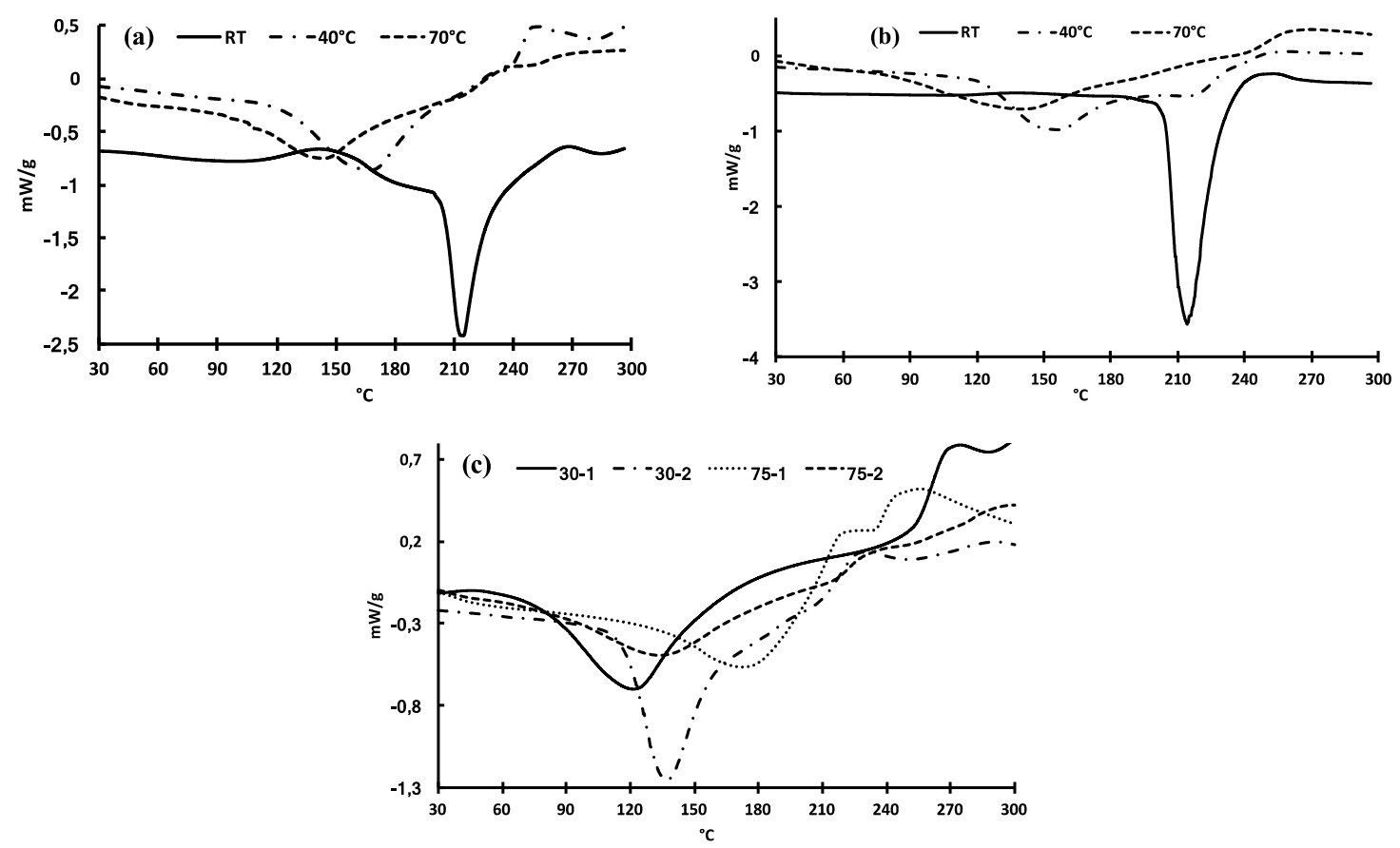

Figure 6. Thermal heating curves of the samples extracted by magnetic stirring mode during $1 \mathrm{~h} \mathrm{(a)}$ and $48 \mathrm{~h}(\mathbf{b})$ and by UAE (c).

At $40{ }^{\circ} \mathrm{C}$, both the samples show a supplementary lower melting points at around 169 and $157^{\circ} \mathrm{C}$ after 1 and $48 \mathrm{~h}$ of extraction, respectively, while transitions at around $213-214{ }^{\circ} \mathrm{C}$ tend to disappear. These thermograms indicate that samples obtained after longer extraction duration exhibit a decreased thermal stability. At $70{ }^{\circ} \mathrm{C}$, DSC curves present the same trend with a broad transition at around $142{ }^{\circ} \mathrm{C}$ and $146^{\circ} \mathrm{C}$ after 1 and $48 \mathrm{~h}$, respectively. After one hour of extraction, an unobvious shoulder at around $210{ }^{\circ} \mathrm{C}$ can be detected while for a longer time no noticeable shoulder can be detected. The decrease of transition temperatures is consistent to the extraction of numerous macromolecules especially concerning the increase of protein concentrations being likely to evoke transitions associated to the denaturation of these macromolecules [46] and also be probably attributed to the dissociation of the macromolecular entanglement under temperature effect.

The thermal curves of the ultrasonic assisted extractions are shown in Figure 6c. The shape of the DSC heating curves of UAE samples are very similar to the samples obtained by stirring method at $70{ }^{\circ} \mathrm{C}$, which are wider compare to those of the samples obtained at room temperature and $40^{\circ} \mathrm{C}$. This might be due to the degradations caused by both extraction temperature and ultrasound. The mucilage samples are partially degraded into many low molecular fractions leading to the samples with wide and non-uniform compositions and thus lead to broader heating curves. For the $30 \mathrm{~min}$ irradiation periods, the endothermic transition is observed at $123^{\circ} \mathrm{C}$ for the first stage while it is shifted to $138^{\circ} \mathrm{C}$ for the second stage. For a longer irradiation time of $75 \mathrm{~min}$, it is worth to note that the transition of the first stage is maximum at $178^{\circ} \mathrm{C}$ then shift to $138^{\circ} \mathrm{C}$ during the second stage. This result seems to indicate that a longer duration of acoustic irradiation tends to homogenize the samples whose molecular organizations end up being similar as shown in the SEM images.

The enthalpies of all samples are summarized in Table 6. According to the results, we can note that $E_{\mathrm{a}}$ of samples are relatively homogeneous for traditional magnetic stirring extraction while UAE experiments show larger deviations in values. The whole values are representative of molecular mixtures extracted form flaxseed and the interpretation of these thermal data are not easy since this depends on molecular self-assembly, dissociation of molecular entanglement following by potential 
reorganization of supramolecular layout. However, the analysis of thermal UAE data shows a strong disparity of values related to duration and stage. In both cases, the drastic decrease of enthalpy in the second stage can be assigned to the degradation of polysaccharides into monosaccharide fractions.

Table 6. DSC characteristics of flaxseed gum extracted by magnetic stirring and UAE methods.

\begin{tabular}{ccccccc}
\hline $\begin{array}{c}\text { Extraction } \\
\text { Temperature }\end{array}$ & $\begin{array}{c}\text { Extraction } \\
\text { Time }(\mathbf{h})\end{array}$ & $\begin{array}{c}\text { Temperature } \\
\text { Range }\left({ }^{\circ} \mathbf{C}\right)\end{array}$ & $\begin{array}{c}\text { Enthalpy } \\
(\mathbf{J} / \mathbf{g})\end{array}$ & UAE & $\begin{array}{c}\text { Temperature } \\
\text { Range }\left({ }^{\circ} \mathbf{C}\right)\end{array}$ & $\begin{array}{c}\text { Enthalpy } \\
(\mathrm{J} / \mathrm{g})\end{array}$ \\
\hline \multirow{2}{*}{$\mathrm{RT}$} & 1 & $141.7-267.7$ & +318.1 & $30-1$ & $71.2-268.8$ & +494.5 \\
\cline { 2 - 6 } & 48 & $139.0-246.3$ & +379.1 & $30-2$ & $108.1-226.1$ & +285.8 \\
\hline \multirow{2}{*}{$40^{\circ} \mathrm{C}$} & 1 & $114.5-250.9$ & +385.2 & $75-1$ & $88.1-243.4$ & +318.7 \\
\cline { 2 - 5 } & 48 & $114.5-250.9$ & +333.4 & $75-2$ & $88.1-243.4$ & +170.1 \\
\hline \multirow{2}{*}{$70^{\circ} \mathrm{C}$} & 1 & $88.6-236.4$ & +261.4 & & & \\
& 48 & $75.2-258.1$ & +394.7 & & & \\
\hline
\end{tabular}

This DSC analysis demonstrates that the proteins in mucilage samples do not show a clear effect on the thermal behavior of the extracted samples, instead, the extraction parameters do play a key role on the thermal behavior of the extracted samples. Therefore, it reaches the conclusion that the mucilage sample obtained at lower temperature has relatively more uniform compositions and therefore has better physical performance, while those obtained at elevated temperatures or by ultrasonic assisted extraction exhibit relatively broader compositions and therefore exhibit declined physical properties. In addition, based on the DSC analysis, the mucilage sample obtained by traditional magnetic stirring method at room temperature after $48 \mathrm{~h}$ of extraction is promising to be used as thermal plastic film, probably because the compositions of the lignan derivatives and the polysaccharides of mucilage seem to be the good ratio to involve ester linked to form macromolecular complexes.

\section{Conclusions}

In the present work, flax seed mucilage was extracted by magnetic stirring and UAE methods. The flaxseed gum extracted in aqueous solution is a mixture of various components, including polysaccharides, proteins and lignan derivatives. Compared to traditional magnetic stirring method, ultrasonic assisted extraction method can significantly enhance the yield of mucilage, proteins and offers the possibility to access at lignan derivatives. It is interesting to find out that the decrease of the $\mathrm{pH}$ value of the extracted samples is related to the presence of lignan molecules and could be used as a tracking parameter of SDG derivatives. Effect of the proteins on the physical properties of mucilage is much less compared to that of the lignan molecules, as they can be ester-linked to mucilage polysaccharides via hydroxymethylglutarate (HMG) binding to form macromolecule complexes. Though the extraction yield of mucilage is low, the mucilage sample extracted at room temperature by traditional magnetic stirring method is found to have generally homogenous morphology and exhibit better thermal stability.

Future works are expected to design a scaling up of mucilage UAE in order to develop the great impact of acoustic cavitation on the seed extractions. Indeed, the mixture nature of flaxseed mucilage extraction opens diverse possibilities to develop novel formulas targeted to special applications in cosmetics, food, medical and agriculture field, thus future works are also expected to evaluate the health benefits and pharmacological activities of these mixtures.

Supplementary Materials: The following are available online at http://www.mdpi.com/2073-4360/12/11/2654/s1, Figure S1: ${ }^{1} \mathrm{H}$ NMR spectra of the mucilage samples obtained at room temperature, 40 and $70{ }^{\circ} \mathrm{C}$ after different extraction duration (1, 20 and $48 \mathrm{~h}$ ) by traditional magnetic stirring method., Figure S2: ${ }^{13} \mathrm{C}$ NMR spectra of the mucilage samples obtained at (a) room temperature, (b) 40 and (c) $70{ }^{\circ} \mathrm{C}$ after different extraction duration $(1,20$ and $48 \mathrm{~h})$ by traditional magnetic stirring method. 
Author Contributions: Conceptualization, F.D. (Fang Dubois) and F.D. (François Delattre); methodology, F.D. (Fang Dubois); software, F.D. (François Delattre); validation, F.D. (François Delattre); formal analysis, F.D. (François Delattre); investigation, F.D. (Fang Dubois); resources, B.D., C.M., L.T., X.S., I.M.; data curation, C.M., L.T., X.S.; writing-original draft preparation, F.D. (Fang Dubois); writing-review and editing, F.D. (François Delattre); visualization, F.D. (Fang Dubois), C.M., X.S., I.M.; supervision, F.D. (François Delattre); project administration, F.D. (François Delattre); funding acquisition, F.D. (François Delattre). All authors have read and agreed to the published version of the manuscript.

Funding: This research was funded by European Regional Development Fund (NP0008106) and the APC was funded by ULCO.

Acknowledgments: The authors graciously acknowledge Romain Lepez (IRenE) for the administrative support and Steven Ruellan for his technical assistance.

Conflicts of Interest: The authors declare no conflict of interest.

\section{References}

1. Khalifa, M.E.A.; Elgasim, A.E.; Zaghloul, A.H.; Mahfouz, M.B. Applications of inulin and mucilage as stabilizers in yoghurt production. Am. J. Food Technol. 2011, 6, 31-39. [CrossRef]

2. Ganorkar, P.M.; Jain, R.K. Flaxseed-A nutritional punch. Int. Food. Res. J. 2013, 20, 519-525.

3. Muralikrishna, G.; Salimath, P.V.; Tharanathan, R.N. Structural features of an arabinoxylan and a rhamno-galacturonan derived from linseed mucilage. Carbohydr. Res. 1987, 161, 265-271. [CrossRef]

4. Oomah, B.D.; Der, T.J.; Godfrey, D.V. Thermal characteristics of flaxseed (Linum usitatissimum L.) proteins. Food Chem. 2006, 98, 733-741. [CrossRef]

5. Wanasundara, J.P.D.; Shahidi, F. Functional properties and amino-acid composition of solvent-extracted flaxseed meals. Food Chem. 1994, 49, 45-51. [CrossRef]

6. Warrand, J.; Michaud, P.; Picton, L.; Muller, G.; Courtois, B.; Ralainirina, R.; Courtois, J. Structural investigations of neutral polysaccharide of Linum usitatissimum L. seeds mucilage. Int. J. Biol. Macromol. 2005, 35, 121-125. [CrossRef]

7. Barbary, O.M.; Al-Sohaimy, S.A.; El-Saadani, M.A. Extraction, composition and physicochemical properties of flaxseed mucilage. J. Adv. Agric. Res. 2009, 14, 605-622.

8. Ziolkovska, A. Laws of flaxseed mucilage extraction. Food Hydrocol. 2012, 26, 197-204. [CrossRef]

9. Kaushik, P.; Dowling, K.; Adhikari, R.; Barrow, C.J.; Adhikari, B. Effect of extraction temperature on composition, structure and functional properties of flaxseed gum. Food Chem. 2017, 215, 333-340. [CrossRef]

10. Cui, W.; Mazza, G.; Biliaderis, C.G. Chemical structure, molecular size distribution and rheological properties of flaxseed gum. J. Agric. Food Chem. 1994, 42, 1891-1895. [CrossRef]

11. Fabre, J.F.; Lacroux, E.; Valentin, R.; Mouloungui, Z. Ultrasonication as a highly efficient method of flaxseed mucilage extraction. Ind. Crops Prod. 2015, 65, 354-360. [CrossRef]

12. Mason, T.J.; Chemat, F.; Vinatoru, M. The extraction of natural products using ultrasound or microwaves. Curr. Org. Chem. 2011, 15, 237-247. [CrossRef]

13. Alix, S.; Marias, S.; Morvan, C.; Lebrun, L. Biocomposite materials from flax plants: Preparation and properties. Compos. Part A 2008, 39, 1793-1801. [CrossRef]

14. Dubois, M.; Gilles, K.A.; Hamilton, J.K.; Rebers, P.A.; Smith, F. Colorimetric method for determination of sugars and related substance. Anal. Chem. 1956, 28, 350-356. [CrossRef]

15. Blumenkrantz, N.; Absoe-Hansen, G. New methods for quantitative determination of uronic acids. Anal. Biochem. 1973, 54, 484-489. [CrossRef]

16. Melton, L.D.; Smith, B.G. Determination of the Uronic acid content of plant cell walls using a colorimetric assay. In Current Protocols in Food Analytical Chemistry; John Wiley and sons Inc.: New York, NY, USA, 2001.

17. Smith, P.K.; Kronh, R.I.; Hermanson, G.T. Measurement of protein using bicinchoninic acid. Anal. Biochem. 1985, 150, 76-85. [CrossRef]

18. Broido, A. A simple, sensitive graphical method of treating thermogravimetric analysis data. J. Polym. Sci. 1969, 7, 1761-1773. [CrossRef]

19. MacCallum, J.R. Comprehensive Polymer Science; Pergamon Press: Oxford, UK, 1989; Volume 1, Chapter 37.

20. Kaewmanne, T.; Bagnasco, L.; Benjakul, S.; Lanteri, S.; Morelli, C.F.; Speranza, G.; Cosulich, M.E. Characterisation of mucilages extracted from seven Italian cultivars of flax. Food Chem. 2014, 148, 60-69. [CrossRef] 
21. Kost, J.; Leong, K.; Langer, R. Ultrasound enhanced polymer degradation and release of incorporated substances. Proc. Natl. Acad. Sci. USA 1989, 86, 7663-7666. [CrossRef]

22. Gilbert, B.C.; King, D.M.; Thomas, C.B. The oxidation of some polysaccharides by the hydroxyl radical: An E.S.R investigation. Carbohyd. Res. 1984, 125, 217-235. [CrossRef]

23. Ramsay, A.; Fliniaux, O.; Fang, J.; Molinie, R.; Roscher, A.; Grand, E.; Guillot, X.; Kovensky, J.; Fliniaux, M.A.; Schneider, B.; et al. Development of an NMR metabolomics-based tool for selection of flaxseed varieties. Metabolomics 2014, 10, 1258-1267. [CrossRef]

24. Ding, H.H.; Qian, K.; Douglas Goff, H.; Wang, Q.; Cui, S.W. Structural and conformational characterization of arabinoxylans from flaxseed mucilage. Food Chem. 2018, 254, 266-271. [CrossRef] [PubMed]

25. Eliasson, C.; Kamal-Eldin, A.; Andersson, R.; Aman, P. High performance liquid chromatographic analysis of secoisolariciresinol diglucoside and hydroxycinnamic acid glucosides in flax seed by alkaline extraction. J. Chromatogr. A 2003, 1012, 151-159. [CrossRef]

26. Struijs, K.; Vincken, J.P.; Verhoef, R.; Voragen, A.G.J.; Gruppen, H. Hydroxycinnamic acids are ester-linked directly to glucosyl moieties within the lignan macromolecule from flaxseed hulls. Phytochemistry 2008, 69, 1250-1260. [CrossRef] [PubMed]

27. Manach, C.; Scalbert, A.; Morand, C.; Rémésy, C.; Jiménez, L. Polyphenols: Food sources and bioavailability. Am. J. Clin. Nutr. 2004, 79, 727-747. [CrossRef]

28. Ford, J.D.; Huang, K.S.; Wang, H.B.; Davin, L.B.; Lewis, N.G. Biosynthetic pathway to the cancer chemopreventive secoisolariciresinol diglucoside-hydroxymethyl glutaryl ester-linked lignan oligomers in flax (Linum usitatissimum) seed. J. Nat. Prod. 2001, 64, 1388-1397. [CrossRef] [PubMed]

29. Struijs, K.; Vincken, J.P.; Doeswijk, T.G.; Voragen, A.G.J.; Gruppen, H. The chain length of lignan macromolecule from flaxseed hulls is determined by the incorporation of coumaric acid glucosides and ferulic acid glucosides. Phytochemistry 2009, 70, 262-269. [CrossRef]

30. Gerstenmeyer, E.; Reimer, S.; Berghofer, E.; Schwartz, H.; Sontag, G. Effect of thermal heating on some lignans in flax seeds, sesame seeds and rye. Food Chem. 2013, 138, 1847-1855. [CrossRef]

31. Johnsson, P.; Peerlkamp, N.; Kamal-Eldin, A.; Andersson, R.E.; Andersson, R.; Lundgren, L.N.; Aman, P. Polymeric fractions containing phenol glucosides in flaxseed. Food Chem. 2002, 76, 207-212. [CrossRef]

32. Sicilia, T.; Niemeyer, H.B.; Honig, D.M.; Metzler, M. Identification and stereochemical characterization of lignans in flaxseed and pumpkin seeds. J. Agric. Food Chem. 2003, 51, 1181-1188. [CrossRef]

33. Attoumbré, J.; Laoualy, A.B.M.; Bienaimé, C.; Dubois, F.; Baltora-Rosset, S. Investigation of lignan accumulation in developing Linum usitatissimum seeds by immunolocalization and HPLC. Phytochem. Lett. 2011, 4, 194-198. [CrossRef]

34. Fang, J.; Ramsay, A.; Renouard, S.; Hano, C.; Lamblin, F.; Chabbert, B.; Mesnard, F.; Schneider, B. Laser microdissection and spatiotemporal pino-lariciresinol reductase gene expression assign the cell layer-specific accumulation of secoisolariresinol diglucoside in flaxseed coats. Front. Plant Sci. 2016, 7, 1-14. [CrossRef] [PubMed]

35. Krimmel, B.; Swoboda, F.; Solar, S.; Reznicek, G. OH-radical induced degradation of hydroxybenzoic- and hydroxycinnamic acids and formation of aromatic products-A gamma radiolysis study. Rad. Phys. Chem. 2010, 79, 1247-1254. [CrossRef]

36. Bhatty, R.S. Further compositional analyses of flax: Mucilage, trypsin inhibitors and hydrocyanic acid. JAOCS 1993, 71, 899-904. [CrossRef]

37. Corbin, C.; Fidel, T.; Leclerc, E.A.; Barakzoy, E.; Sagot, N.; Falguiéres, A.; Renouard, S.; Blondeau, J.-P.; Ferroud, C.; Doussot, J.; et al. Development and validation of an efficient ultrasound assisted extraction of phenolic compounds from flax (Linum usitatissimum L.) seeds. Ultrason. Sonochem. 2015, 26, 176-185. [CrossRef] [PubMed]

38. Chen, H.-H.; Xu, S.-Y.; Wang, Z. Gelation properties of flaxseed gum. J. Food Eng. 2006, 77, $295-303$. [CrossRef]

39. Baeza, R.I.; Carp, D.J.; Pérez, O.E.; Pilosof, A.M.R. k-Carrageenan protein interactions: Effect of proteins on polysaccharide gelling and textural properties. LWT Food Sci. Technol. 2002, 35, 741-747. [CrossRef]

40. Loginov, M.; Boussetta, N.; Lebovka, N.; Vorobiev, E. Separation of polyphenols and proteins from flaxseed hull extracts by coagulation and ultrafiltration. J. Membr. Sci. 2013, 442, 177-186. [CrossRef]

41. Back, J.F.; Oakenfull, D.; Smith, M.B. Increased thermal stability of proteins in the presence of sugars and polyols. Biochemistry 1979, 18, 5191-5196. [CrossRef] 
42. Tschierske, C. Amphotropic liquid crystals. Curr. Opin. Colloid Interface Sci. 2002, 7, 355-370. [CrossRef]

43. Rogers, M.A.; Feng, Q.; Ladizhansky, V.; Good, D.B.; Smith, A.K.; Corridini, M.; Grahame, D.A.S.; Bryska, B.C.; Jadhav, P.D.; Sammynaiken, S.; et al. Self-assembled fibrillary networks comprised of a naturally-occurring cyclic pepetide-LOB3. RSC Adv. 2016, 6, 40765-40776. [CrossRef]

44. Arzeni, C.; Martinez, K.; Zema, P.; Arias, A.; Pérez, O.E.; Pilosof, A.M.R. Comparative study of high intensity ultrasound effects on food proteins functionality. J. Food Eng. 2012, 108, 463-472. [CrossRef]

45. Zohurian, M.J.; Shokrolahi, F. Thermal studies on natural and modified gums. Polym. Test. 2003, 23, 575-579. [CrossRef]

46. Oomah, B.D.; Kenaschuk, E.O.; Cui, W.; Mazza, G. Variation in the composition of water-soluble polysaccharides in flaxseed. J. Agri. Food Chem. 1995, 43, 1484-1488. [CrossRef]

Publisher's Note: MDPI stays neutral with regard to jurisdictional claims in published maps and institutional affiliations.

(C) 2020 by the authors. Licensee MDPI, Basel, Switzerland. This article is an open access article distributed under the terms and conditions of the Creative Commons Attribution (CC BY) license (http://creativecommons.org/licenses/by/4.0/). 